\title{
PREPRINT
}

Posted on 04/11/2020

DOI: https://doi.org/10.3897/arphapreprints.e60362

\section{Polychaetes (Annelida) associated with macroalgae and coral reefs at a protected tropical island from the Atlantic coast}

(D) Dimitri Costa, (D) Jessica Prata, Martin Christoffersen

Not peer-reviewed, not copy-edited manuscript.

Disclaimer on biological nomenclature and use of preprints

The preprints are preliminary versions of works accessible electronically in advance of publication of the final version. They are not issued for purposes of botanical, mycological or zoological nomenclature and are not effectively/validly published in the meaning of the Codes. Therefore, nomenclatural novelties (new names) or other nomenclatural acts (designations of type, choices of priority between names, choices between orthographic variants, or choices of gender of names) should NOT be posted in preprints. The following provisions in the Codes of Nomenclature define their status:

International Code of Nomenclature for algae, fungi, and plants (ICNafp)

Article 30.2: "An electronic publication is not effectively published if there is evidence within or associated with the publication that its content is merely preliminary and was, or is to be, replaced by content that the publisher considers final, in which case only the version with that final content is effectively published." In order to be validly published, a nomenclatural novelty must be effectively published (Art. 32.1(a)); in order to take effect, other nomenclatural acts must be effectively published (Art. 7.10, $11.5,53.5,61.3$, and 62.3).

International Code of Zoological Nomenclature (ICZN)

Article: 21.8.3: "Some works are accessible online in preliminary versions before the publication date of the final version. Such advance electronic access does not advance the date of publication of a work, as preliminary versions are not published (Article 9.9)". 


\title{
Polychaetes (Annelida) associated with macroalgae and coral reefs at a protected tropical island from the Atlantic coast
}

\author{
Dimítri de Araújo Costa ${ }^{\ddagger} \S$, Jessica Pratal, Martin Lindsey Christoffersen§ \\ ‡ CIIMAR - Interdisciplinary Centre of Marine and Environmental Research, University of Porto, Matosinhos, Portugal \\ § UFPB - Federal University of Paraíba, DSE - Department of Systematics and Ecology, João Pessoa, Brazil \\ I UFPB - Federal University of Paraiba, DCB - Department of Biological Sciences, Areia, Brazil
}

Corresponding author: Dimítri de Araújo Costa (dimitri.costa@ciimar.up.pt)

\begin{abstract}
Background

Polychaetes are typical marine invertebrates in the macroalgae and coral reefs environments, with a particular emphasis on tropical waters. In this study, 44 specimens were collected, belonging to 10 families, 13 genera and 13 species, among which the families Nereididae (with three species) and Amphinomidae (two spp.) were the most representative. The species Terebella plagiostoma (10 individuals), Ceratonereis singularis (9) and Eurythoe complanata (9) were the most abundant.
\end{abstract}

\section{New information}

This work represents the first study of polychaetes performed at the Morro de São Paulo region (Tinharé Island), a protected island from Northeast Brazil (state of Bahia). The samples (algae in the fringing reef ecosystems) were collected in 2015, at low tide in the intertidal to shallow subtidal zones. The species Hyboscolex longiseta Schmarda, 1861 is reported here for the first time in the South Atlantic Ocean. The errant polychaetes predominated at the collected samples $(61.36 \%$ of the total abundance). These numbers evidence how little we know about coastal marine invertebrate fauna in Brazil and indicate the need for further sampling, especially on protected islands.

\section{Keywords}

Marine worms, Morro de São Paulo, Northeast Brazilian, taxonomy, new records 


\section{Introduction}

Reef ecosystems are extremely complex and productive, harbouring a significant portion of the biodiversity of the oceans, including trophic levels intrinsically linked with the benthic food web (Henry and Roberts 2016). Globally, around 250,00 marine species are described (WoRMS Editorial Board 2020), nevertheless one-third to two-third still to be described (Appeltans et al. 2012), especially in reef environments. Although there are many studies with coral reefs, those involving associated macrofauna remain insipient.

Brazil has a long coastal zone that extends from $04^{\circ} 30^{\prime} \mathrm{N}$ to $33^{\circ} 44^{\prime} \mathrm{S}$, with a total area of approximately $1,550,000 \mathrm{~km}^{2}$ subdivided into 16 marine sedimentary basins. The coast between the northern border of Brazil with French Guiana $\left(5^{\circ} \mathrm{N}\right)$ to the southeastern region of the country (state of Espírito Santo: $20^{\circ} \mathrm{S}$ ) comprises tropical marine ecoregions in the South Atlantic Ocean (Spalding et al. 2007) with extensive, complex reef ecosystems that harbour a rich community of metazoans.

The state of Bahia (Northeastern Brazil) has about $1,000 \mathrm{~km}$ of coastline and a considerable variety of coastal ecosystems (e.g., coral reefs, mangroves and rocky, sandy or muddy beaches) (Short and Klein 2016). This coastal zone harbours considerable biodiversity (Amaral and Jablonski 2005), mainly between Todos os Santos Bay $\left(12^{\circ} \mathrm{S}\right)$ and the Abrolhos Archipelago ( $17^{\circ} \mathrm{S}$ ), and is highly important for the implementation of conservation practices (Amado-Filho et al. 2012, Lopez et al. 2015).

Marine invertebrates in shallow reef ecosystems off northeastern Brazil have been underresearched (Amaral and Jablonski 2005, DeOliveiraSoares et al. 2016). Insufficient knowledge on this and other Brazilian ecosystems has been demonstrated based on the high number of records and/or descriptions of molluscs, pycnogonids, polychaetes and echinoderms (e.g. Barroso and Paiva 2007, Gondim et al. 2014, Costa et al. 2017, Prata et al. 2017, Prata et al. 2020, Lima et al. 2019).

Faunistic surveys documenting the biodiversity of marine invertebrates in coastal ecosystems off northeastern Brazil are far from satisfactory. In recent decades, however, studies have expanded knowledge on benthic invertebrate fauna in the region. In 2005, a studied about the benthic macrofauna performed on Paracuru beach (state of Ceará), detected that the most of assemblage was mainly composed of Crustacea Brünnich, 1772, Mollusca Linnaeus, 1758 and Polychaeta Grube, 1850 (Viana et al. 2005). In Areia Vermelha Marine State Park (municipality of Cabedelo, state of Paraíba) 102 species belonging to the Ascidiacea, Cnidaria, Crustacea, Echinodermata and Mollusca taxa were found (Gondim et al. 2011). Correia and Sovierzoski listed a total of 102 endemic species of poriferans, cnidarians and echinoderms living in reef ecosystems off northeastern Brazil (Correia and Sovierzoski 2013). At the Sebastião Gomes Reef and Abrolhos Archipelago, the macrofauna associated with the brown algae from genus Dictyota spp. was evaluated, providing a faunal list of Crustacea, Polychaeta and Mollusca (Cunha et al. 2013). New 
surveys are needed due to the rapid degradation of tropical coastal ecosystems, especially reefs, as a result of human activities that are causing the disappearance of species.

The present study aimed to document the polychaete diversity associated with algae in the reef ecosystems of Morro de São Paulo on Tinharé Island in the state of Bahia, northeastern Brazil, which is an under-explored area from the zoological standpoint.

\section{Materials and methods}

\section{Study area}

The study area on the coast of the state of Bahia belongs to an Environmental Protection Area (EPA) denominated "Tinharé-Boipeba", which was established in 1992. The area has about $433 \mathrm{~km}^{2}$ and is located between the mouth of the Patos River and Taperoá Channel, belonging to the Tropical Northwestern Marine Ecoregion (Spalding et al. 2007). The present study was conducted in the intertidal and shallow subtidal zones of Morro de São Paulo (1322'56.0" S, 38 $\left.54^{\prime} 32.1^{\prime \prime} \mathrm{W}\right)$, which is located on Tinharé Island in the municipality of Cairú, state of Bahia, northeastern Brazil (Fig. 1).

Morro de São Paulo has three main beaches, denominated First, Second and Third Beaches, which have a large influx of tourists (Elliff and Kikuchi 2017). This coastal environment is characterized mainly by fringing reefs that line the coast and are exposed at low tide. The top of these reefs has an irregular, truncated surface that is cut by channels, giving rise to tide pools (Kikuchi et al. 2008). The fringing reefs are close to the beach line and form discontinuous structures in shallower regions. A large concentration of organisms, such as algae, corals, sponges, molluscs, crustaceans, echinoderms and fish, is found in the tide pools and channels.

\section{Sampling methods and analysis}

Samples were collected on January $21^{\text {st }}$ and $22^{\text {nd }}, 2015$, from reef ecosystems of the First, Second and Third Beaches of Morro de São Paulo (Tinharé Island) at low tide in the intertidal to shallow subtidal zones at depths to about $1 \mathrm{~m}$.

Polychaetes and algae were collected manually at different points of the study area and stored in plastics bags with seawater. Immediately after collection, algae were stored in large buckets for two hours in a makeshift laboratory to reduce the stress of the associated invertebrates. The polychaetes were subsequently separated from the algae. All specimens were preserved in $70 \%$ ethanol. Most were photographed under a stereomicroscope and some individuals were photographed in situ. Identification was primarily based on the respective literature (e.g. Nonato and Luna 1970, Amaral and Nonato 1996, Costa et al. 2017).

Diversity indexes was calculated for the polychaete fauna as a whole based on the abundance of the material collected. The collector curve and the biodiversity calculations 
were made using the EstimateS statistical software (Colwell 2013). Graphs were created using the Excel program.

All the material analyzed is deposited and available for study at the "Coleção de Invertebrados Paulo Young" (CIPY, Invertebrate Collection Paulo Young), "Departamento de Sistemática e Ecologia" (DSE, Department of Systematics and Ecology), "Universidade Federal da Paraíba" (UFPB, Federal University of Paraíba), João Pessoa, Paraíba, Brazil.

\section{Identified polychaetes from the Morro de São Paulo, Northeast}

\section{Brazil}

\section{Subclass Errantia Audouin \& Milne Edwards, 1832}

\section{Order Amphinomida Fauchald, 1977}

\section{Family Amphinomidae Lamarck, 1818}

Diagnosis: Prostomium with a protuberant nuchal organ known as 'caruncle', formed by folds and ciliated tracts, connected to posterior region of prostomium (Fauchald and Rouse 1997).

\section{Eurythoe complanata (Pallas, 1766)}

- WoRMS http://www. marinespecies.org/aphia.php?p=taxdetails\&id=129829

\section{Material}

a. individualCount: 9; catalogNumber: UFPB.POL-1718; recordedBy: D. A. Costa, J. Prata

Diagnosis: Prostomium with two pairs of eyes, three antennae, two palps, and a caruncle arranged in one series of 6-7 lobes, extending to chaetiger 2. Branchiae ramified from chaetiger 2 onwards. Parapodium with slender dorsal and ventral cirri; notopodia (dorsal) with following kinds of chaetae: furcate, smooth, serrated, and a slender blade with a small spur; neuropodia (ventral) with furcate chaetae (Barroso and Paiva 2007, Arias et al. 2013) (Fig. 2a).

Distribution: Caribbean Sea to Brazilian coast (Ceará, Rio Grande do Norte, Paraíba, Pernambuco, Alagoas, Bahia, Espírito Santo, Rio de Janeiro, São Paulo states); Iberian Peninsula to Red Sea; Azores Archipelago; East Africa; Pacific Ocean (Oceania to South America, and Hawaii) (DeAssis et al. 2012, Amaral et al. 2013, Costa et al. 2017, Read and Fauchald 2020a). Type locality: Caribbean Sea.

Notes: First record in Morro de São Paulo (Tinharé Island), State of Bahia, Northeast Brazil. 


\section{Hermodice carunculata (Pallas, 1766)}

- WoRMS http://www.marinespecies.org/aphia.php?p=taxdetails\&id=129831

\section{Material}

a. $\quad$ individualCount: 1; catalogNumber: UFPB.POL-1717; recordedBy: D. A. Costa, J. Prata

Diagnosis: Prostomium with two pairs of eyes, three antennae, two palps; caruncle consisting of two series of 6 to 9 leaflike lobes, expanding to chaetiger 4 . Branchiae ramified from chaetiger 1 onwards. Parapodium with slender dorsal and ventral cirri; notopodia with smooth and pointed chaetae; neuropodia carry spurred chaetae with serrations (Barroso and Paiva 2007) (Fig. 2b).

Distribution: Gulf of Mexico to Brazilian coast (Rio Grande do Norte, Paraíba, Pernambuco, Bahia states); Azores Archipelago; Ascension Island; Mediterranean Sea; Red Sea (DeAssis et al. 2012, Amaral et al. 2013, Read and Fauchald 2020b). Type locality: Gulf of Mexico.

Notes: First record in Morro de São Paulo (Tinharé Island), State of Bahia, Northeast Brazil.

\section{Order Eunicida Fauchald, 1977}

\section{Family Eunicidae Berthold, 1827}

Diagnosis: 1, 3 or 5 antennae; types of chaetae: falcigers, spinigers, limbate, pectinate, and subacicular hooks (Fauchald and Rouse 1997).

\section{Marphysa stylobranchiata Moore, 1909}

\section{- WoRMS http://www.marinespecies.org/aphia.php?p=taxdetails\&id=329267}

\section{Material}

a. individualCount: 1; catalogNumber: UFPB.POL-1722; recordedBy: D. A. Costa, J. Prata

Diagnosis: Prostomium with a short anterior incision, with two eyes, and five antennae. Jaws eulabidognath-type (asymmetrical, posterior parts dentate to forceps-like, short carriers). Branchiae with only one filament from chaetiger 20. Anterior dorsal cirri longer than posterior ones. Neuropodia with cirri smaller than dorsal ones; falcigers chaetae; 1-5 dark aciculae, and dark subacicular unidentate hooks (Nonato and Luna 1970, Knox and Green 1972, Paxton 2009) (Fig. 2c).

Distribution: California, Brazilian coast (Paraíba, Alagoas, Bahia, and Rio de Janeiro states) (Amaral et al. 2013, Costa et al. 2017, Read and Fauchald 2020c). Type locality: Monterey Bay, California (USA). 
Notes: First record in Morro de São Paulo (Tinharé Island), State of Bahia, Northeast Brazil.

\section{Order Phyllodocida Dales, 1962}

\section{Family Chrysopetalidae Ehlers, 1864}

Diagnosis: Notochaetae paleal-type (thick, flattened and metallic-like modified chaetae) (Fauchald and Rouse 1997).

\section{Bhawania obscura (Grube, 1868)}

- WoRMS http://www.marinespecies.org/aphia.php?p=taxdetails\&id=333103

Material

a. individualCount: 1; catalogNumber: UFPB.POL-1723; recordedBy: D. A. Costa, J. Prata

Diagnosis: Prostomium retractable between the anterior segments, with two pairs of eyes, three antennae. Dorsum recovered with enlarged and symmetrical paleae chaetae. Dorsal cirri retractable. Notopodia only carry paleae, neuropodia with falcigers and spinigers chaetae (Amaral and Nonato 1994) (Fig. 2d).

Distribution: Brazilian coast (Paraíba, Rio de Janeiro and Santa Catarina states) (Amaral et al. 2013, Costa et al. 2017, Read and Fauchald 2020d). Type locality: Santa Catarina (Brazil).

Notes: First record in Morro de São Paulo (Tinharé Island), State of Bahia, Northeast Brazil.

\section{Family Nereididae Blainville, 1818}

Diagnosis: T-shaped prostomium; birramous parapodia with robust notopodial lobes; notochaetae falcigers and spinigers (Fauchald and Rouse 1997).

\section{Ceratonereis singularis Treadwell, 1929}

- WoRMS http://www.marinespecies.org/aphia.php?p=taxdetails\&id=327401

\section{Material}

a. individualCount: 9; catalogNumber: UFPB.POL-1727; recordedBy: D. A. Costa, J. Prata

Diagnosis: Prostomium with four eyes, two antennae, and two palps. Proboscis with conical paragnaths (areas I and V, VII and VIII no ones, area II with 9-15 long oval group ones, area III with 6-10 group triangular ones, area IV with 10-16 oval group ones, and area VI with a cushion-like lobe), and jaws with 5-6 teeth. Four pairs of anterior tentacular cirri ("modified cirri"). Parapodia with notopodial and neuropodial 
lobes (with pre and post-chaetal ones), falcigers and spinigers chaetae, and dark aciculae (Perkins 1980, Santos and Lana 2003) (Fig. 2e).

Distribution: In the Western Atlantic Ocean: North Carolina, southeast Florida, Gulf of Mexico, Caribbean Sea, Colombia, northeast Brazil (Maranhão, Rio Grande do Norte, Paraíba, and Alagoas states) (Amaral et al. 2013). Eastern Pacific Ocean: Mexico to Panamá (Santos and Lana 2003, DeAssis et al. 2012, Amaral et al. 2013, Costa et al. 2017, Read and Fauchald 2020e). Type locality: San Jose Island, Lower California (Mexico).

Notes: First record in Morro de São Paulo (Tinharé Island), State of Bahia, Northeast Brazil.

\section{Nereis riisei Grube, 1857}

\section{- WoRMS http://www.marinespecies.org/aphia.php?p=taxdetails\&id=329735}

\section{Material}

a. individualCount: 4; catalogNumber: UFPB.POL-1726; recordedBy: D. A. Costa, J. Prata

Diagnosis: Prostomium with four eyes, two antennae, and two palps. Proboscis with conical paragnaths (area I with one structure, area II 10 ones, area III with 18-20 ones, area IV with 26-30 ones, area V no ones, area VI with six ones, area VII and VIII with five ones), and serrated jaws. Four pairs of anterior tentacular cirri. Parapodia with notopodial and neuropodial lobes (with pre and post-chaetal ones), falcigers and spinigers chaetae, and dark aciculae (Uebelacker and Johnson 1984, Santos and Lana 2003, Amaral et al. 2005) (Fig. 3a).

Distribution: Distribution: Pacific Ocean: Mexico (Santa Maria Bay, Gulf of California, Guerrero, Socorro Island), Costa Rica (Nicoya Gulf, Papagayo Gulf), Panama (Gorgona Island, Coiba Island), Colombia (Gorgona Island) and Ecuador (La Libertad, Galapagos Island). Atlantic Ocean: Gulf of Mexico (Florida, Texas, Veracruz, Ciudad del Carmen, Alacranes Reef, Cayo Arcas, Triangulos Oeste, Cayo Nuevo), Mexico, Panama, Cuba, Bonaire, Anguilla, St Eustatius, Aruba, Curaçao, Barbados, St Vincent, Grenada, Barbuda, Antigua, Jamaica, Venezuela, Colombia, and Brazil (Pará, Maranhão, Piauí, Ceará, Rio Grande do Norte, Paraíba, Pernambuco, Alagoas, Bahia, Espírito Santo, Rio de Janeiro, São Paulo, Paraná, and Santa Catarina States) (Santos and Lana 2003, DeAssis et al. 2012, Amaral et al. 2013, Costa et al. 2017, Read and Fauchald 2020f). Type locality: Caribbean Sea.

Notes: First record in Morro de São Paulo (Tinharé Island), State of Bahia, Northeast Brazil.

\section{Pseudonereis gallapagensis Kinberg, 1865}

- WoRMS http://www. marinespecies.org/aphia.php?p=taxdetails\&id=209794 


\section{Material}

\section{a. $\quad$ individualCount: 1; catalogNumber: UFPB.POL-1728; recordedBy: D. A. Costa, J. Prata}

Diagnosis: Prostomium with four eyes, two antennae, and two palps. Proboscis with paragnaths (area I with two conical ones, area II with three rows of pectinate bars, area III with four pectinate bars, area IV with five pectinate bars, area $\mathrm{V}$ with one conical paragnath, area VI with transverse ones, and areas VII and VIII with a single row conical ones), and serrated jaws. Four pairs of anterior tentacular cirri. Parapodia with notopodial and neuropodial lobes (with pre and post-chaetal ones), falcigers and spinigers chaetae, and dark aciculae (Dueñas-Ramírez and Quiros-Rodriguez 2012) (Fig. 3b).

Distribution: Atlantic Ocean: Gulf of Mexico, Panama, Brazil (Rio Grande do Norte, Paraíba, Pernambuco, São Paulo, and Paraná States), and South Africa. Indian Ocean, and Pacific Ocean: Ecuador (Galapagos Islands), Peru and Chile (Trovant et al. 2012, Amaral et al. 2013, Costa et al. 2017, Read and Fauchald 2020g). Type locality: Galapagos archipelago (Ecuador).

Notes: First record in Morro de São Paulo (Tinharé Island), State of Bahia, Northeast Brazil.

\section{Family Phyllodocidae Örsted, 1843}

Diagnosis: Notopodial cirri leaf-like; chaetae only spinigers-type, distally inflated shafts (Fauchald and Rouse 1997).

\section{Phyllodoce schmardaei Day, 1963}

- WoRMS http://www.marinespecies.org/aphia.php?p=taxdetails\&id=330630

\section{Material}

a. individualCount: 1; catalog Number: UFPB.POL-1724; recordedBy: D. A. Costa, J. Prata

Diagnosis: Body greenish. Prostomium with two eyes, four antennae, nuchal organs, and a small posterior-median papilla. Proboscis divided at two parts, proximal one with soft papillae, distal one papillated with six divisions. Four pairs of anterior tentacular cirri (Day 1967a) (Fig. 3c).

Distribution: Pacific Ocean: Mexico (Oaxaca) (Chávez-López and Cruz-Gómez 2019). Atlantic Ocean: Brazil (Paraíba and São Paulo states) and South Africa (Day 1967a, Amaral et al. 2013, Costa et al. 2017, Read and Fauchald 2020h). Type locality: False Bay (South Africa).

Notes: First record in Morro de São Paulo (Tinharé Island), State of Bahia, Northeast Brazil. 


\section{Subclass Sedentaria Lamarck, 1818}

\section{Order Opheliida Fauchald, 1977}

\section{Family Opheliidae Malmgren, 1867}

Diagnosis: Thin and tapered body ('fusiform'); conical prostomium, and mouth with a transverse opening at the level of chaetiger 1 (Fauchald and Rouse 1997).

\section{Armandia maculata (Webster, 1884)}

- WoRMS http://www. marinespecies.org/aphia. $p h p ? p=t a x d e t a i l s \& i d=157220$

Material

a. individualCount: 1; catalogNumber: UFPB.POL-1721; recordedBy: D. A. Costa, J. Prata

Diagnosis: Prostomium tapered with nuchal organs and three eyespots. Proboscis saclike with digitiform papillae. Branchiae smooth on most chaetigers. Parapodia with pre and post chaetal lobes. 11 pairs of lateral eyes at both sides of medium chaetigers (from 6 or 7 one). Chaetae only capillary type (Elías et al. 2003) (Fig. 3d).

Distribution: New Zealand, Trinidad and Tobago, Bermuda, North Carolina to Gulf of Mexico, Caribbean Sea, Brazilian coast (Paraíba, Pernambuco, Alagoas, Bahia, Rio de Janeiro, São Paulo, Paraná, Santa Catarina, and Rio Grande do Sul States) (DeAssis et al. 2012, Amaral et al. 2013, Read and Fauchald 2020i). Type locality: Bermuda archipelago.

Notes: First record in Morro de São Paulo (Tinharé Island), State of Bahia, Northeast Brazil.

\section{Family Scalibregmatidae Malmgren, 1867}

Diagnosis: Epidermis highly wrinkled. Prostomium bilobed truncate or T-shaped, without antennae (Fauchald and Rouse 1997).

\section{Hyboscolex longiseta Schmarda, 1861}

\section{- WoRMS http://www. marinespecies.org/aphia.php?p=taxdetails\&id=209886}

\section{Material}

a. individualCount: 1; catalogNumber: UFPB.POL-1725; recordedBy: D. A. Costa, J. Prata

Diagnosis: Prostomium with two lateral projections (T-shaped). Two fused pairs of wide eyes beneath the peristomial fold. Body without parapodial projections or branchiae. 
Chaetae emerging directly from the epidermis. Chaetae of type capillaries or lyrate. Five anal cirri (Day 1967b, Díaz-Díaz and Liñero-Arana 2004) (Fig. 4a).

Distribution: Venezuela, Gulf of Mexico, Mediterranean Sea, South Africa, Mozambique, Egypt (Red Sea), New Zealand (Day 1967b, Díaz-Díaz and Liñero-Arana 2004, Read and Fauchald 2020j). Type locality: Table Bay (South Africa).

Notes: The species represents a new record from Western Atlantic Ocean.

\section{Order Sabellida Levinsen, 1883}

\section{Family Sabellidae Latreille, 1825}

Diagnosis: Elongated anterior part of thoracic hooks; serrated main tooth of thoracic uncini (Fauchald and Rouse 1997).

\section{Branchiomma nigromaculatum (Baird, 1865)}

- WoRMS http://www. marinespecies.org/aphia. $p h p ? p=t a x d e t a i l s \& i d=209930$

\section{Material}

a. individualCount: 4; catalogNumber: UFPB.POL-1719; recordedBy: D. A. Costa, J. Prata

Diagnosis: Prostomium fused to peristomium, developing a prostomial branchial crown. With black spots all over the body. Membrane joining the base of the radiolar crown. 46 pairs of radioles, with stylodes and dark brown, white and orange bands bands; 5-6 ventralmost radioles on each side without stylodes, arising from inrolled parts of crown basis; rachis with segmented appearance. Thoracic unciniger ('tori') carry avicular uncini. Presence of collar chaetae like as compact fascicles (Tovar-Hernández and Knight-Jones 2006) (Fig. 4b).

Distribution: Gulf of Mexico, Caribbean Sea, Brazilian coast (Paraíba, Pernambuco, Alagoas, Sergipe, Bahia, Espírito Santo, Rio de Janeiro, and São Paulo States), East Africa (Tovar-Hernández and Knight-Jones 2006, DeAssis et al. 2012, Amaral et al. 2013, Costa et al. 2017, Read and Fauchald 2020k). Type locality: Caribbean Sea.

Notes: First record in Morro de São Paulo (Tinharé Island), State of Bahia, Northeast Brazil.

\section{Order Terebellida Rouse \& Fauchald, 1997}

\section{Family Flabelligeridae Saint-Joseph, 1894}

Diagnosis: Branchiae above the peristomial membrane (Fauchald and Rouse 1997). 


\section{Pherusa scutigera (Ehlers, 1887)}

\section{- WoRMS http://www.marinespecies.org/aphia.php?p=taxdetails\&id=334492}

\section{Material}

a. $\quad$ individualCount: 1; catalogNumber: UFPB.POL-1729; recordedBy: D. A. Costa, J. Prata

Diagnosis: Prostomium reduced like a slender edge. Papillae covering the body. Anterior region prolonged by a translucent membranous tube. Chaetae 1-3 iridescent, forming a cephalic cage. A waistline marks the transition between the anterior segments and the posterior ones. Chaetigers 1-5 with capillaries chaetae; following segments with ventral aciculae chaetae (Nonato and Luna 1970) (Fig. 4c).

Distribution: Caribbean Sea, Brazilian coast (Paraíba, Sergipe, Rio de Janeiro, São Paulo, and Rio Grande do Sul States) (Amaral et al. 2013, Costa et al. 2017, Read and Fauchald 2020l). Type locality: Caribbean Sea.

Notes: First record in Morro de São Paulo (Tinharé Island), State of Bahia, Northeast Brazil.

\section{Family Terebellidae Johnston, 1846}

Diagnosis: Numerous sulcate/grooved prostomial palps (Fauchald and Rouse 1997).

\section{Terebella plagiostoma Schmarda, 1861}

\section{Material}

a. individualCount: 10; catalogNumber: UFPB.POL-1720; recordedBy: D. A. Costa, J. Prata

Diagnosis: Prostomium fused to anterior border of peristomium, carrying a tentacular lobe horseshoe-shaped and grooved tentacles; eyespots in two or three rows on the posterior margin of the tentacular lobe. Segment 6 with three pairs branchiae with spiral filaments. Notochaetae capillaries-like arranged in two rows. Uncini arising from the chaetiger 3; uncinigers ('tori') from segment 2 (Rozbaczylo et al. 2006) (Fig. 4d).

Distribution: Brazilian coast (Paraíba and Rio de Janeiro states), South Africa, Mozambique, Madagascar, Zanzibar, Red Sea, New Zealand (Amaral et al. 2013, Costa et al. 2017, Read and Fauchald 2020m). Type locality: New Zealand.

Notes: First record in Morro de São Paulo (Tinharé Island), State of Bahia, Northeast Brazil. 


\section{Identification keys}

\section{Polychaetes identification key from the Morro de São Paulo, Northeast Brazil}

1 Prostomium with a caruncle (conspicuous nuchal organs) - Family

Amphinomidae

2

3

- Prostomium without caruncle

2 Caruncle extending to chaetiger 3 , carrying a median lobe

Eurythoe complanata

Caruncle with two series of foliaceous lobes, extending to chaetiger 4

Prostomium with five antennae, branchiae with single filaments Family Eunicidae

- Prostomium 0-4 antennae

Prostomium with three antennae, dorsum of the body covered with golden brown paleal chaetae - Family Chrysopetalidae

- Prostomium 0, 2 or 4 antennae

Prostomium with two antennae, birramous parapodia - Family Nereididae

- $\quad$ Prostomium 0 or 4 antennae

6roboscis with paragnaths in areas II to IV, and VI (areas I and V, VII and VIII no cirri or chaetae)

- Proboscis with paragnaths in other organization position Proboscis with paragnaths in areas I to IV, and VI to VIII (area V no cirri or chaetae)

- Proboscis with paragnaths in all areas

8 Prostomium with four antennae, parapodia carry dorsal enlarged foliaceous cirri - Family Phyllodocidae

- Prostomium without antennae, sedentary polychaetes

\begin{tabular}{|l}
\hline $\begin{array}{l}\text { Hermodice } \\
\text { carunculata }\end{array}$ \\
$\begin{array}{l}\text { Marphysa } \\
\text { stylobranchiata }\end{array}$ \\
\hline 4 \\
\hline Bhawania obscura \\
\hline 5 \\
\hline 6 \\
\hline 8 \\
\hline $\begin{array}{l}\text { Ceratonereis } \\
\text { singularis }\end{array}$ \\
\hline 7 \\
\hline Nereis riisei \\
\hline \begin{tabular}{l} 
Pseudonereis \\
gallapagensis \\
\hline schmardaei
\end{tabular} \\
\hline 9 \\
\hline
\end{tabular}




\begin{tabular}{|c|c|c|}
\hline 9 & $\begin{array}{l}\text { Prostomium with tapered end, lateral eyes in median segments - } \\
\text { Family Opheliidae }\end{array}$ & Armandia maculata \\
\hline- & Prostomium with lateral processes or rounded & 10 \\
\hline 10 & $\begin{array}{l}\text { Prostomium T-shaped (with anterior lateral processes), five anal cirri } \\
\text { - Family Scalibregmatidae }\end{array}$ & Hyboscolex longiseta \\
\hline- & Prostomium reduced or fused with peristomium & 11 \\
\hline 11 & $\begin{array}{l}\text { Prostomium fused to peristomium, developing a prostomial branchial } \\
\text { crown - Family Sabellidae }\end{array}$ & $\begin{array}{l}\text { Branchiomma } \\
\text { nigromaculatum }\end{array}$ \\
\hline- & Prostomium reduced or partially fused to peristomium & 12 \\
\hline 12 & $\begin{array}{l}\text { Prostomium reduced like a slender edge, body covered by } \\
\text { papillae, anterior chaetae forming a 'cage' - Family Flabelligeridae }\end{array}$ & Pherusa scutigera \\
\hline- & $\begin{array}{l}\text { Prostomium fused to anterior border of peristomium, } \\
\text { carrying tentacular lobe horseshoe-shaped - Family Terebellidae }\end{array}$ & Terebella plagiostoma \\
\hline
\end{tabular}

\section{Analysis}

\section{Structure of the polychaete assemblage}

A total of 44 polychaetes (Annelida) were collected, belonging to 6 orders (Amphinomida, Eunicida, Phyllodocida, Opheliida, Sabellida and Terebellida), 10 families and 13 species. The species were mainly associated with the following algae: Halimeda opuntia (Linnaeus) J.V. Lamouroux, 1816 Sargassum polyceratium Montagne, 1837; Lithothamnium sp., Ulva lactuca Linnaeus, 1753 and Gracilaria caudata J. Agardh, 1852.

In general, the errant polychaetes predominated at the collected samples $(61.36 \%$ of the total abundance), i.e. Eurythoe complanata (Pallas, 1766); Hermodice carunculata (Pallas, 1766); Marphysa stylobranchiata Moore, 1909; Bhawania obscura (Grube, 1868); Ceratonereis singularis Treadwell, 1929; Nereis riisei Grube, 1857; Pseudonereis gallapagensis Kinberg, 1865; and Phyllodoce schmardaei Day, 1963. The most abundant species were Terebella plagiostoma Schmarda, 1861 (10 individuals), E. complanata and C. singularis with nine individuals. N. riisei and Branchiomma nigromaculatum (Baird, 1865) obtained four specimens each, and the others with one each. The families Nereididae Blainville, 1818 (with three species) and Amphinomidae Lamarck, 1818 (two spp.) were the most representative.

Most specimens were found associated with the aforementioned algae. The species Hyboscolex longiseta Schmarda, 1861 is reported here for the first time in the South Atlantic. The Ace and Chao 1 diversity indices estimated both 40.36 species for the polychaete species. 


\section{Discussion}

The calculated estimative indices highlighted the importance of continuing to conduct studies in the region (with the need to increase the sampling effort), regarding both the fauna as a whole and each taxon. In the individual analyses, with only 13 species sampled, whereas about 40 species were estimated, indicating a large gap to be filled, even if one considers that total diversity is underestimated. Another important aspect to consider is that the study area is located between Todos os Santos Bay and the Abrolhos Archipelago, which is recognized as one of the most diversified ecoregions along the Brazilian coast and is a priority coastal zone for conservation purposes (Rhormens et al. 2017).

Despite the likely underestimations, a considerable diversity of polychaetes was found in the present study. Such diversity levels for the region have also been verified studying the phytobenthos on Boipeba Island, which is in the same vicinity as Tinharé Island (Moura et al. 2015). The authors collected 159 taxa, which is a number similar to that found for oceanic islands in Brazil. Nonetheless, the richness of polychaetes in the study (13 spp.) was lower than that found at the Abrolhos Bank, 90 and 41 respectively (Paiva 2005, Figueiredo et al. 2007), and in the estuary of the Cachoeira River (23), in the state of Bahia (Ourives et al. 2011). The present study is the first to be carried out specifically in the Morro São Paulo environment (Tinharé Island), therefore all species identified here represented new records for this island.

Several shallow-water habitats in Brazil, especially on the extensive coast of Bahia, still require inventories for a better understanding of polychaete assemblages. Knowledge on the annelid fauna in coastal ecosystems of this region has become somewhat more accurate in recent years.

The species $H$. longiseta is considered the first record for the South Atlantic coast, representing also the third Scalibregmatidae Malmgren, 1867 for the Brazilian coast (only Asclerocheilus tropicus Blake, 1981 from the São Paulo state, and Scalibregma inflatum Rathke, 1843 from São Paulo and Rio de Janeiro states (Amaral et al. 2013)), and the first record of this family for the Northeast Brazilian coast.

Taxonomic studies on polychaetes (involving the identification of several families) for the region Northeast Brazilian have increased in a spotty fashion and even these annelids are considered insufficiently known. One the first large taxonomic studies in this region (Ceará, Rio Grande do Norte, Paraíba, Alagoas and Sergipe states) was performed Edmundo Nonato and José Luna, identifying a total of 71 species (Nonato and Luna 1969, Nonato and Luna 1970). In the Maranhão state coast, 38 species were identified in a compiled bibliography study (Ribeiro and Almeida 2014). In particular, for the Paraíba state, 49 species were registered at the Seixas Beach (Costa et al. 2017), and all coast of this state 122 species are known at the moment (DeAssis et al. 2012, Costa et al. 2017). Studies focusing in only one family also were realizing in the northeast, e.g. family Amphinomidae for the Rocas Atoll (Rio Grande do Norte state) (Barroso and Paiva 2007), Nereididae for 
the Paraíba and Ceará coast (Santos and Lana 2001, Santos and Lana 2003). Studies in Bahia state (where is located Morro São Paulo) are still insipient and low representative.

The data from this study are related to the sampling method employed, mainly selecting specimens associated with algae and coral reefs. The species Eurythoe complanata (Pallas, 1766), B. obscura, M. stylobranchiata, Pherusa scutigera (Ehlers, 1887), C. singularis, N. riisei, P. gallapagensis, P. schmardaei, B. nigromaculatum and T. plagiostoma are associated with rhodolith beds (Corallinales, Rhodophyta), possible using these biogenic structures as a nursery (Costa et al. 2019). The species from families Amphinomidae (E. complanata), Phyllodocidae (Phyllodoce spp.), Nereididae (C. singularis , Nereis sp., Pseudonereis), Eunicidae (Marphysa sp.), Opheliidae (Armandia sp.), Terebellidae (Terebella spp.) are associated with coral reefs (Bailey-Brock 1999).

This work clearly shows that the reef ecosystems of Morro de São Paulo exhibit an important potential for a greater diversity of polychaetes that has not been taxonomically studied over the years. This invertebrate community in the study area has been affected by multiple anthropogenic impacts, such as pollution as well as the trampling and collecting of individuals by tourists and fishermen. Further studies in the region are needed for a better understanding of polychaete fauna and the increasing impact of human activities (pollution and tourism), e.g. a study that evaluated the touristic impact in Paraíba state coast (Costa et al. 2019). Besides, local governments need to develop conservation strategies and act more effectively to impede the capture of threatened invertebrates.

\section{Conclusions}

This represents the first taxonomic study of the polychaete fauna from Tinhare Island (Bahia state), a tropical protected area that is essential for the maintenance of marine life. It estimated approximately 40 polychaete species with the increase of sampling effort. The species $H$. loginseta is considered as a new record from South Atlantic. The diversity of these annelids still is substimated, being indispensable most studies to know the marine diversity in the Northeast Brazilian coast, mainly in islands.

\section{Acknowledgements}

This study was financed partially by the Coordination for the Improvement of Higher Education Personnel (CAPES/Brazil) - Finance Code 001; and Portuguese funds attributed to Interdisciplinary Centre of Marine and Environmental Research (CIIMAR) through the Foundation for Science and Technology (FCT) within the scope of UIDB/04423/2020 and UIDP/04423/2020. The authors acknowledge the support provided by the Federal University of Paraíba (UFPB/Campus I), Department of Systematics and Ecology, Invertebrate Laboratory Paulo Young ("Laboratório de Invertebrados Paulo Young"/LIPY), Brazil. Special thanks to Regional Post-Graduation Programme in Development and Environment (PRODEMA/UFPB) by the academic support. D.A. Costa was supported by a Ph.D. scholarship provided by Doctoral Program Sandwich Abroad (PDSE)/CAPES ("Edital n 47/2017"), in partnership with "Fundação de Apoio à Pesquisa do Estado da Paraíba" 
(FAPESQ) ("Edital n 03/2016"). J. Prata was supported by a Ph.D. scholarship/CAPES/ Brazil . M.L. Christoffersen thanks the productivity grant provided by the National Council for Scientific and Technological Development (CNPq/Brazil).

\section{Author contributions}

D. Costa wrote the manuscript, identified and described the polychaete species. J. Prata designed the study and implemented it in the beaches, and prepared the plates/polychaete photos and the study area figure. D. Costa, J. Prata and M. Christoffersen interpreted and analysed the data. M. Christoffersen was the English proofreader. The manuscript was then revised by all authors.

\section{References}

- $\quad$ Amado-Filho GM, Moura RL, Bastos AC, Salgado LT, Sumida PY, Guth AZ, FranciniFilho RB, Pereira-Filho GH, Abrantes DP, Brasileiro PS, Bahia RG, Leal RN, Kaufman L, Kleypas JA, Farina M, Thompson FL (2012) Rhodolith beds are major CaCO3 biofactories in the tropical South West Atlantic. PLOS One 7 (4): e35171. https://doi.org/ 10.1371/journal.pone.0035171

- $\quad$ Amaral A, Jablonski S (2005) Conservation of marine and coastal biodiversity in Brazil. Conservation Biology 19 (3): 625-631. https://doi.org/10.1111/j.1523-1739.2005.00692.x

- Amaral ACZ, Nonato E (1994) Polychaete from Brazilian coast: 5. Pisionidae, Chrysopetalidae, Amphinomidae and Euphrosinidae. Revista Brasileira de Zoologia 11 (2): 361-390. https://doi.org/10.1590/S0101-81751994000200022

- Amaral ACZ, Nonato E (1996) Annelida Polychaeta: características, glossário e chaves para famílias e gêneros da costa brasileira. [Annelida Polychaeta: characteristics, glossary and keys for families and genera from the Brazilian coast]. UNICAMP, Campinas, 124 pp. URL: https://www.ib.unicamp.br/museu zoologia/catalogos guias [ISBN 9788526803756]

- $\quad$ Amaral ACZ, Rizzo AE, Arruda EP (2005) Manual de identificação dos invertebrados marinhos da região Sudeste-Sul do Brasil. [Manual of identification of the marine invertebrates from the Southeast-South region from Brazil]. EDUSP, São Paulo, 288 pp. URL: https://www.edusp.com.br/detlivro.asp?ID=408946 [ISBN 9788531408946]

- $\quad$ Amaral ACZ, Nallin SH, Steiner TM, Forroni T, Gomes-Filho D (2013) Catálogo das espécies de Annelida Polychaeta do Brasil. [Catalogue of the Annelida Polychaeta species from Brazil]. UNICAMP, Campinas, 141 pp. URL: https://www.ib.unicamp.br/ museu zoologia/sites/www.ib.unicamp.br.museu zoologia/files/

\section{Catálogo Polychaeta Brasil Amaral et al 2013 1a.pdf}

- $\quad$ Appeltans W, Ahyong ST, Anderson G, Angel MV, Artois T, Bailly N, Bamber R, Barber A, Bartsch I, Berta A, Błażewicz-Paszkowycz M, Bock P, Boxshall G, Boyko CB, Brandão SN, Bray RA, Bruce NL, Cairns SD, Chan T, Cheng L, Collins AG, Cribb T, Curini-Galletti M, Dahdouh-Guebas F, Davie PJF, Dawson MN, De Clerck O, Decock W, De Grave S, de Voogd NJ, Domning DP, Emig CC, Erséus C, Eschmeyer W, Fauchald K, Fautin DG, Feist SW, Fransen CHJM, Furuya H, Garcia-Alvarez O, Gerken S, Gibson D, Gittenberger A, Gofas S, Gómez-Daglio L, Gordon DP, Guiry MD, Hernandez 
F, Hoeksema BW, Hopcroft RR, Jaume D, Kirk P, Koedam N, Koenemann S, Kolb JB, Kristensen RM, Kroh A, Lambert G, Lazarus DB, Lemaitre R, Longshaw M, Lowry J, Macpherson E, Madin LP, Mah C, Mapstone G, McLaughlin PA, Mees J, Meland K, Messing CG, Mills CE, Molodtsova TN, Mooi R, Neuhaus B, Ng PKL, Nielsen C, Norenburg J, Opresko DM, Osawa M, Paulay G, Perrin W, Pilger JF, Poore GCB, Pugh P, Read GB, Reimer JD, Rius M, Rocha RM, Saiz-Salinas JI, Scarabino V, Schierwater B, Schmidt-Rhaesa A, Schnabel KE, Schotte M, Schuchert P, Schwabe E, Segers H, Self-Sullivan C, Shenkar N, Siegel V, Sterrer W, Stöhr S, Swalla B, Tasker ML, Thuesen EV, Timm T, Todaro MA, Turon X, Tyler S, Uetz P, van der Land J, Vanhoorne B, van Ofwegen LP, van Soest RWM, Vanaverbeke J, Walker-Smith G, Walter TC, Warren A, Williams GC, Wilson SP, Costello MJ (2012) The magnitude of global marine species diversity. Current biology 22 (23): 2189-202. https://doi.org/10.1016/j.cub.2012.09.036

- $\quad$ Arias A, Barroso R, Anadón N, Paiva P (2013) On the occurrence of the fireworm Eurythoe complanata complex (Annelida, Amphinomidae) in the Mediterranean Sea with an updated revision of the alien Mediterranean amphinomids. ZooKeys 337: 19-33. https://doi.org/10.3897/zookeys.337.5811

- Bailey-Brock J (1999) Ecology and biodiversity of coral reef polychaetes of Guam and Saipan, Mariana Islands. International Review of Hydrobiology 84 (2): 181-196. https:// doi.org/10.1002/iroh.199900019

- $\quad$ Barroso R, Paiva PC (2007) Amphinomidae (Annelida: Polychaeta) from Rocas Atoll, Northeastern Brazil. Arquivos do Museu Nacional, Rio de Janeiro 65 (3): 357-362. URL: http://museunacional.ufrj.br/publicacoes/?page id=879

- Chávez-López Y, Cruz-Gómez C (2019) New records of polychaetes (Annelida: Polychaeta) from three locations of Oaxaca, Mexico. Revista de Biología Tropical 67 (S5): S157-S168. https://doi.org/10.15517/rbt.v67is5.38941

- $\quad$ Colwell R (2013) EstimateS 9.1.0 User's Guide. http://viceroy.eeb.uconn.edu/estimates/. Accessed on: 2020-10-28.

- Correia MD, Sovierzoski HH (2013) Endemic marine benthic invertebrates on the Brazilian reef ecosystems. Journal of Earth Science and Engineering 3 (10): 672-682. https://doi.org/10.17265/2159-581X/2013.10.003

- Costa DA, Fernandes HF, Silva FA, Christoffersen ML (2017) Checklist de espécies de Polychaeta (Annelida) da Praia do Seixas, João Pessoa, Estado da Paraíba, Nordeste do Brasil. Revista Brasileira de Gestão Ambiental e Sustentabilidade 4 (8): 313-320. https://doi.org/10.21438/rbgas.040806

- Costa DA, Silva FA, Silva JML, Pereira AR, Dolbeth M, Christoffersen ML, Lucena RFP (2019) Is tourism affecting polychaete assemblages associated with rhodolith beds in Northeastern Brazil? Revista de Biología Tropical 67 (S5): S1-S15. https://doi.org/ 10.15517/rbt.v67is5.38922

- Cunha TJ, Güth AZ, Bromberg S, Sumida PYG (2013) Macrofauna associated with the brown algae Dictyota spp. (Phaeophyceae, Dictyotaceae) in the Sebastião Gomes Reef and Abrolhos Archipelago, Bahia, Brazil. Continental Shelf Research 70: 140-149. https://doi.org/10.1016/i.csr.2013.09.001

- Day JH (1967a) A monograph on the Polychaeta of southern Africa. Part. 1. Errantia. British Museum (Natural History), London, 458 pp. https://doi.org/10.5962/bhl.title.8596 - Day JH (1967b) A monograph on the polychaeta of southern Africa. Part. 2. Sedentaria. British Museum (Natural History), London, 450 pp. https://doi.org/10.5962/bhl.title.8596 
- DeAssis JE, Alonso C, Brito RJ, Santos AS, Christoffersen ML (2012) Polychaetous annelids from coast of Paraíba State. Revista Nordestina de Biologia 21 (1): 3-45. URL: https://periodicos.ufpb.br/index.php/revnebio/article/view/13625

- DeOliveiraSoares M, DaCruzLotufo TM, Vieira LM, Salani S, Hadju E, MatthewsCascon H, DeAndradeNeryLeão ZM, DeKikuchi RKP (2016) Brazilian marine animal forests: a new world to discover in the Southwestern Atlantic. In: Rossi S, Bramanti L, Gori A, Orejas C (Eds) Marine Animal Forests. Springer International Publishing, Cham, 38 pp. [ISBN 9783319170015]. https://doi.org/10.1007/978-3-319-17001-5 51-1

- Díaz-Díaz O, Liñero-Arana I (2004) New records of Scalibregmatidae (Annelida: Polychaeta) in the Northeastern Venezuelan region. Boletín del Centro de Investigaciones Biológicas 38 (1): 32-40. URL: https://produccioncientificaluz.org/ index.php/boletin/article/view/16

- Dueñas-Ramírez PR, Quiros-Rodriguez JA (2012) Occurrence of Pseudonereis gallapagensis Kinberg, 1865 (Annelida: Polychaeta: Nereididae) in the Colombian Caribbean coast. Revista Colombiana de Ciencia Animal - RECIA 4 (2): 454-457. https://doi.org/10.24188/recia.v4.n2.2012.225

- $\quad$ Elías R, Bremec CS, Lana PdC, Orensanz JM (2003) Opheliidae (Polychaeta) from the Southwestern Atlantic ocean, with the description of Travisia amadoi n. sp., Ophelina gaucha n. sp. and Ophelina alata n. sp. Hydrobiologia 496 (1-3): 75-85. https://doi.org/ 10.1023/A:1026172126482

- $\quad$ Elliff C, Kikuchi RP (2017) Ecosystem services provided by coral reefs in a Southwestern Atlantic Archipelago. Ocean \& Coastal Management 136: 49-55. https:// doi.org/10.1016/j.ocecoaman.2016.11.021

- $\quad$ Fauchald K, Rouse G (1997) Polychaete systematics: Past and present. Zoologica Scripta 26 (2): 71-138. https://doi.org/10.1111/j.1463-6409.1997.tb00411.x

- $\quad$ Figueiredo MA, SantosdeMenezes K, Costa-Paiva EM, Paiva PC, Ventura CR (2007) Experimental evaluation of rhodoliths as living substrata for infauna at the Abrolhos Bank, Brazil. Ciencias Marinas 33 (4): 427-440. https://doi.org/10.7773/cm.v33i4.1221

- Gondim Al, Dias TLP, Campos FF, Alonso C, Christoffersen ML (2011) Benthic macrofauna from Areia Vermelha Marine State Park, Cabedelo, Paraíba, Brazil. Biota Neotropica 11 (2): 75-86. https://doi.org/10.1590/S1676-06032011000200009

- Gondim AI, Dias TLP, Duarte RCS, Riul P, Lacouth P, Christoffersen ML (2014) Filling a knowledge gap on the biodiversity of rhodolith-associated Echinodermata from Northeastern Brazil. Tropical Conservation Science 7 (1): 87-99. https://doi.org/ 10.1177/194008291400700112

- Henry L, Roberts JM (2016) Global biodiversity in cold-water coral reef ecosystems. In: Rossi S, Bramanti L, Gori A, Orejas C (Eds) Marine Animal Forests. Springer International Publishing, Cham, 21 pp. [ISBN 9783319170015]. https://doi.org/ 10.1007/978-3-319-17001-5 6-1

- Kikuchi RP, Oliveira MM, Leão ZAN, Silva R, Martins PR (2008) Anais da Rio Oil \& Gas Expo and Conference 2008. Rio Oil \& Gas Expo and Conference, Rio de Janeiro, September 15 to 18. Instituto Brasileiro de Petróleo, Gás e Biocombustíveis, Rio de Janeiro, 8 pp. URL: https://www.ibp.org.br/

- Knox GA, Green K (1972) The polychaetes of New Zealand: part 4. Eunicidae. Journal of the Royal Society of New Zealand 2 (4): 459-470. https://doi.org/

10.1080/03036758.1972.10423294 
- $\quad$ Lima SFB, Lima BV, Abreu EC, Oliveira GSP, Lucena RA, Mendonça LMC, Prata J, Souza JWS (2019) First inventory of benthic mollusks associated with the reef ecosystems of Morro de São Paulo on Tinharé Island in northeastern Brazil. Biota Neotropica 19 (4): e20190745. https://doi.org/10.1590/1676-0611-bn-2019-0745

- Lopez G, Saliés E, Lara P, Tognin F, Marcovaldi M, Serafini T (2015) Coastal development at sea turtles nesting ground: efforts to establish a tool for supporting conservation and coastal management in northeastern Brazil. Ocean \& Coastal Management 116: 270-276. https://doi.org/10.1016/j.ocecoaman.2015.07.027

- Moura CWN, Alves AM, Santos AA, Almeida WR, Moniz-Brito KL, Oliveira IS, Freitas NS, Oliveira IB, Ramos GJP (2015) Checklist of phytobenthos from Boipeba Island, Bahia, Brazil, emphasizing the morphological features of Nitophyllum punctatum (Rhodophyta, Ceramiales). Check List 11 (4): 1-11. https://doi.org/10.15560/11.4.1704

- $\quad$ Nonato E, Luna J (1969) Sobre alguns poliquetas de escama do nordeste do Brasil. Boletim do Instituto Oceanográfico 18 (1): 63-91. https://doi.org/10.1590/ $\underline{\text { S0373-55241969000100008 }}$

- $\quad$ Nonato E, Luna J (1970) Anelídeos poliquetas do Nordeste do Brasil: I - poliquetas bentônicos da costa de Alagoas e Sergipe. Boletim do Instituto Oceanográfico 19: 57-130. https://doi.org/10.1590/S0373-55241970000100004

- Ourives T, Rizzo A, Boehs G (2011) Composition and spatial distribution of the benthic macrofauna in the Cachoeira River estuary, Ilhéus, Bahia, Brazil. Revista de Biología Marina y Oceanografía 46 (1): 17-25. https://doi.org/10.4067/ S0718-19572011000100003

- Paiva P (2005) Soft-bottom polychaetes of the Abrolhos Bank. In: Dutra G, Allen G, Werner T, McKenna S (Eds) A rapid marine biodiverstity assessment of the Abrolhos Bank, Bahia, Brazil. RAP Bulletin of Biological Assessment 38. Conservation International, Washington D.C., 4 pp. URL: http://www.geocities.ws/ppoliqueta/ Paiva2006.pdf

- $\quad$ Paxton H (2009) Phylogeny of Eunicida (Annelida) based on morphology of jaws. Zoosymposia 2 (1): 241-264. https://doi.org/10.11646/zoosymposia.2.1.18

- Perkins T (1980) Review of species previously referred to Ceratonereis mirabilis, and descriptions of new species of Ceratonereis, Nephtys, and Goniada (Polychaeta). Proceedings of the Biological Society of Washington 93 (1): 1-49. URL: https:// www.biodiversitylibrary.org/part/43898\#/summary

- $\quad$ Prata J, Costa DA, Manso CLC, Crispim MC, Christoffersen ML (2017) Echinodermata associated to rhodoliths from Seixas Beach, State of Paraíba, Northeast Brazil. Biota Neotropica 17 (3): e20170363. https://doi.org/10.1590/1676-0611-bn-2017-0363

- Prata J, Lucena RA, Lima SFB, Souza JWS, Christoffersen ML (2020) Species richness of Pycnogonida and Echinodermata associated with the reef ecosystems of Morro de São Paulo on Tinharé Island in Northeastern Brazil. International Journal of Development Research 10 (4): 34943-34951. URL: http://www.journalijdr.com/speciesrichness-pycnogonida-and-echinodermata-associated-reef-ecosystems-morro-de-sãopaulo-tinharé

- Read G, Fauchald K (2020a) World Polychaeta database. Eurythoe complanata (Pallas, 1766). http://www. marinespecies.org/aphia. php? $p=t a x d e t a i l s \& i d=129829$. Accessed on: 2020-10-22. 
- $\quad$ Read G, Fauchald K (2020b) World Polychaeta database. Hermodice carunculata (Pallas, 1766). http://www.marinespecies.org/aphia.php?p=taxdetails\&id=129831. Accessed on: 2020-10-22.

- Read G, Fauchald K (2020c) World Polychaeta database. Marphysa stylobranchiata Moore, 1909. http://www. marinespecies.org/aphia. php?p=taxdetails\&id=329267. Accessed on: 2020-10-22.

- Read G, Fauchald K (2020d) World Polychaeta database. Bhawania obscura (Grube, 1868). http://www. marinespecies.org/aphia. php? $p=t a x d e t a i l s \& i d=333103$. Accessed on: 2020-10-22.

- $\quad$ Read G, Fauchald K (2020e) World Polychaeta database. Ceratonereis singularis Treadwell, 1929. http://www. marinespecies.org/aphia. $p h p ? p=t a x d e t a i l s \& i d=327401$. Accessed on: 2020-10-22.

- $\quad$ Read G, Fauchald K (2020f) World Polychaeta database. Nereis riisei Grube, 1857. http://www. marinespecies.org/aphia. $p h p ? p=t a x d e t a i l s \& i d=329735$. Accessed on: 2020-10-22.

- $\quad$ Read G, Fauchald K (2020g) World Polychaeta database. Pseudonereis gallapagensis Kinberg, 1865. http://www. marinespecies.org/aphia. php?p=taxdetails\&id=209794. Accessed on: 2020-10-22.

- Read G, Fauchald K (2020h) World Polychaeta database. Phyllodoce schmardaei Day, 1963. http://www. marinespecies.org/aphia. php? $p=$ taxdetails\&id=330630. Accessed on: 2020-10-23.

- Read G, Fauchald K (2020i) World Polychaeta database. Armandia maculata (Webster, 1884). http://www. marinespecies.org/aphia. php? $p=$ taxdetails\&id=157220. Accessed on: 2020-10-23.

- Read G, Fauchald K (2020j) World Polychaeta database. Hyboscolex longiseta Schmarda, 1861. http://www. marinespecies. org/aphia. php? $p=$ taxdetails\&id=209886. Accessed on: 2020-10-23.

- Read G, Fauchald K (2020k) World Polychaeta database. Branchiomma nigromaculatum (Baird, 1865). http://www.marinespecies.org/aphia.php? $\mathrm{p}=$ taxdetails\&id=209930. Accessed on: 2020-10-23.

- Read G, Fauchald K (2020l) World Polychaeta database. Pherusa scutigera (Ehlers, 1887). http://www.marinespecies.org/aphia. $p h p ? p=t a x d e t a i l s \& i d=334492$. Accessed on: 2020-10-23.

- Read G, Fauchald K (2020m) World Polychaeta database. Terebella plagiostoma Schmarda, 1861. http://www. marinespecies. org/aphia. php? $p=$ taxdetails\&id=340127. Accessed on: 2020-10-23.

- $\quad$ Rhormens MS, Pedrini A, Ghilardi-Lopes NP (2017) Implementation feasibility of a marine ecotourism product on the reef environments of the marine protected areas of Tinharé and Boipeba Islands (Cairu, Bahia, Brazil). Ocean \& Coastal Management 139: 1-11. https://doi.org/10.1016/j.ocecoaman.2017.01.022

- $\quad$ Ribeiro RP, Almeida ZS (2014) Polychaetes Annelids from state of Maranhão, Brazil: History of knowledge. Bioikos 28 (1): 45-55. URL: http://periodicos.puccampinas.edu.br/seer/index.php/bioikos/article/view/2523/1865

- $\quad$ Rozbaczylo N, Moreno R, Díaz-Díaz Ó, Martínez S (2006) Benthic subtidal polychaetes on soft bottoms of the Aysén region of Chile: clade Terebellida (Annelida, Polychaeta). Ciencia y Tecnología del Mar 29 (1): 71-90. URL: http://www.cona.cl/pub/ pub cimar.php\# 
- $\quad$ Santos CG, Lana P (2001) Nereididae (Annelida, Polychaeta) da costa nordeste do Brasil: II. Gêneros Namalycastis, Ceratocephale, Laeonereis e Rullierinereis . Iheringia. Série Zoologia 91: 137-149. https://doi.org/10.1590/s0073-47212001000200020

- Santos CG, Lana P (2003) Nereididae (Polychaeta) da costa nordeste do Brasil: III. Gêneros Ceratonereis e Nereis . Iheringia. Série Zoologia 93 (1): 5-22. https://doi.org/ 10.1590/s0073-47212003000100001

- Short A, Klein A (2016) Brazilian beach systems. 17. Springer International Publishing, Cham, 611 pp. [ISBN 9783319303925] https://doi.org/10.1007/978-3-319-30394-9

- $\quad$ Spalding M, Fox H, Allen G, Davidson N, Ferdaña Z, Finlayson M, Halpern B, Jorge M, Lombana A, Lourie S, Martin K, McManus E, Molnar J, Recchia C, Robertson J (2007) Marine ecoregions of the world: a bioregionalization of coastal and shelf areas.

BioScience 57 (7): 573-583. https://doi.org/10.1641/B570707

- Tovar-Hernández MA, Knight-Jones P (2006) Species of Branchiomma (Polychaeta: Sabellidae) from the Caribbean Sea and Pacific coast of Panama. Zootaxa 1189 (1): 1-37. https://doi.org/10.11646/zootaxa.1189.1.1

- Trovant B, Elías R, Diez M, León-González J (2012) New records of polychaetes (Annelida) for northern Ecuador. Marine Biodiversity Records 5 (3): e32. https://doi.org/ 10.1017/S1755267211001059

- Uebelacker J, Johnson P (1984) Taxonomic guide to the polychaetes of the Northern Gulf of Mexico. Minerals Management Service. Barry A. Vittor \& Associates, Inc., Mobile, 202 pp. https://doi.org/10.5962/bhl.title.4035

- Viana MG, Rocha-Barreira CA, Hijo CAG (2005) Intertidal and surf zone macroinfauna of Paracuru beach (Ceará, Brazil). Brazilian Journal of Aquatic Science and Technology 9 (1): 75-82. https://doi.org/10.14210/bjast.v9n1.p75-82

- WoRMS Editorial Board (2020) World Register of Marine Species. http:// www.marinespecies.org/. Accessed on: 2020-10-21. 


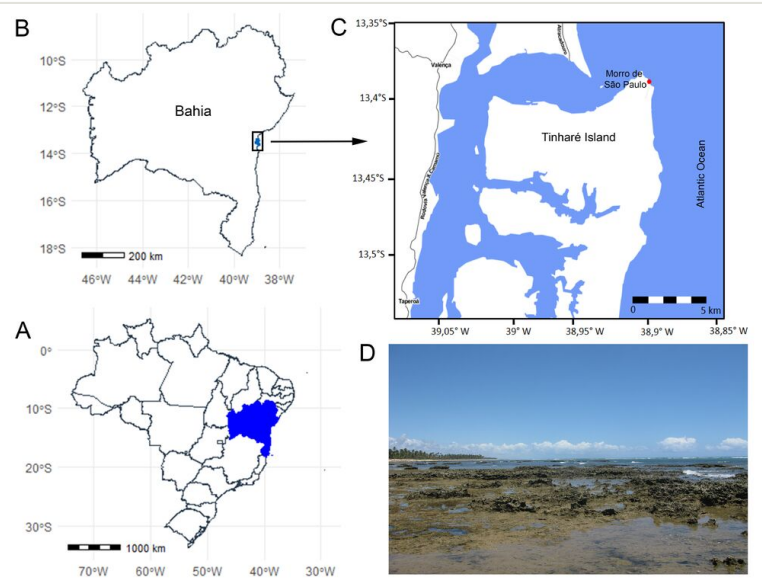

Figure 1.

Study area. A Map of Brazil, with highlight in the state of Bahia B State of Bahia and Cairú municipality C Tinharé Island and Morro de São Paulo area (red point indicates the collection site), D) Reefs from Morro de São Paulo. Geographic Coordinate System: SIRGAS 2000, CRS 4674. Photo: Prata, J. 

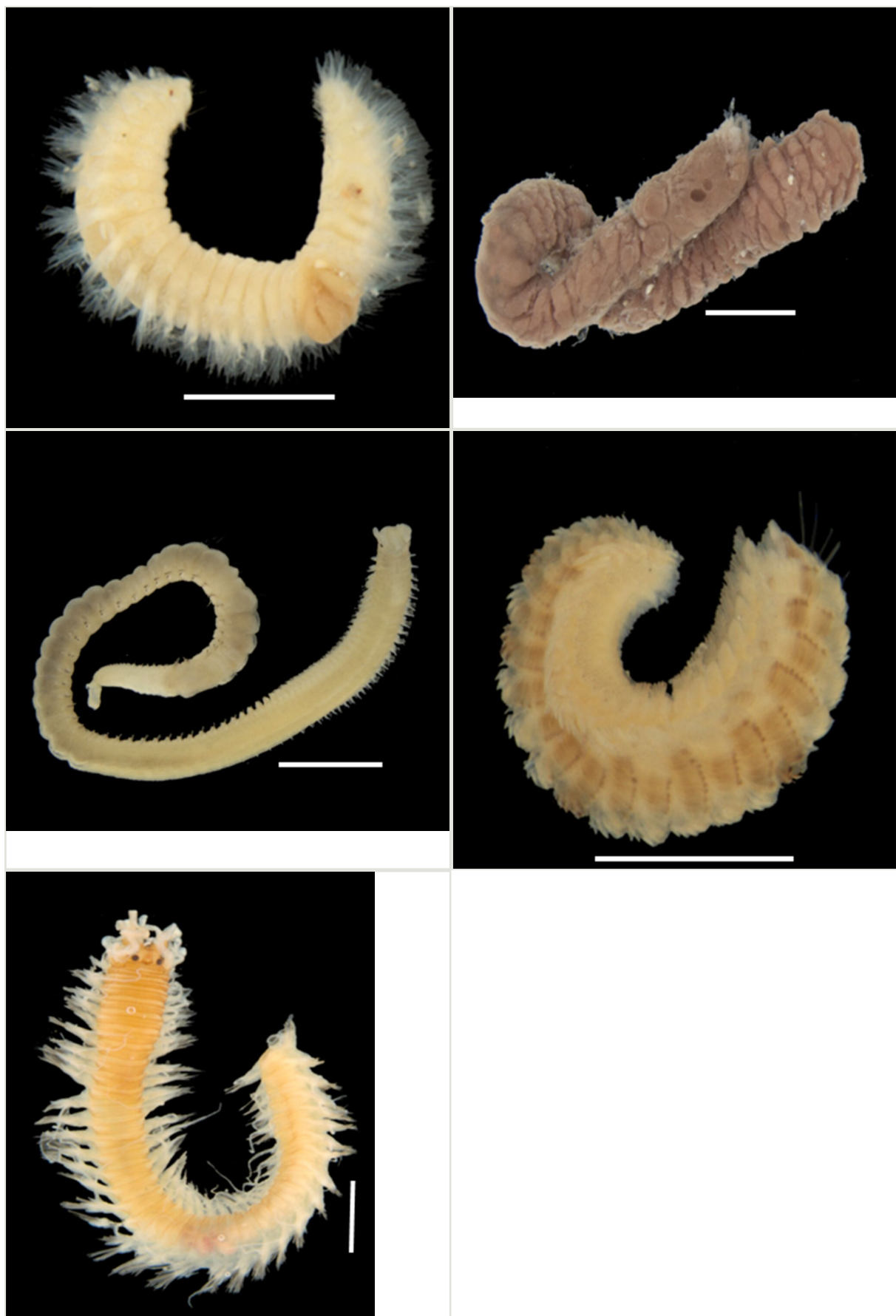

Figure 2.

Identified polychaetes from the Morro de São Paulo, Northeast Brazil. Photos: Prata, J.

a: Eurythoe complanata (Pallas, 1778). Scale bar: $2 \mathrm{~mm}$. Code: UFPB.POL-1718.

b: Hermodice carunculata (Pallas, 1766). Scale bar: 2 mm. Code: UFPB.POL-1717. 
c: Marphysa stylobranchiata Moore, 1909. Scale bar: 2 mm. Code: UFPB.POL-1722.

d: Bhawania obscura (Grube, 1868). Scale bar: $1 \mathrm{~mm}$. Code: UFPB.POL-1723.

e: Ceratonereis singularis Treadwell, 1929. Scale bar: $2 \mathrm{~mm}$. Code: UFPB.POL-1727. 


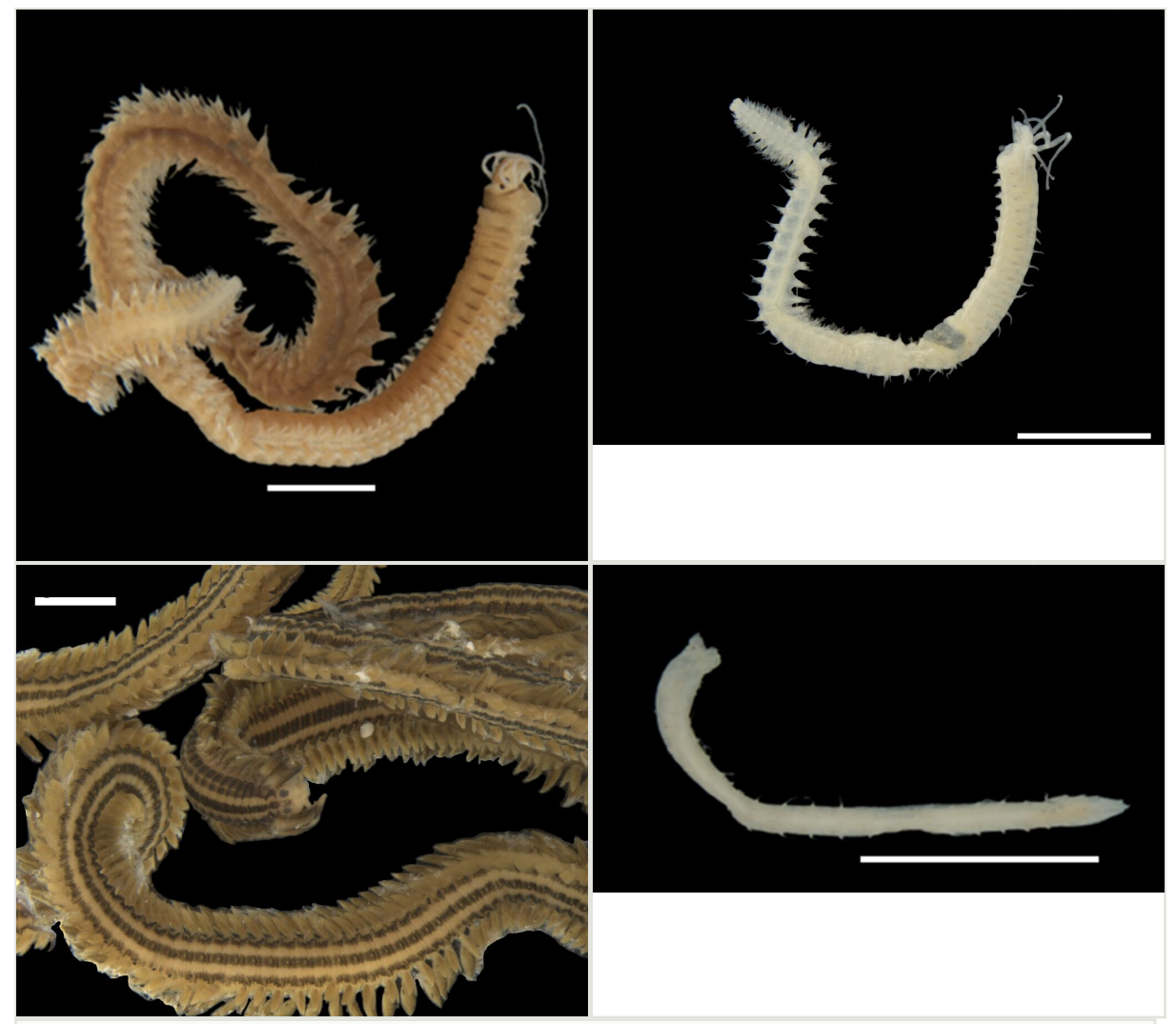

Figure 3.

Identified polychaetes from the Morro de São Paulo, Northeast Brazil. Photos: Prata, J.

a: Nereis riisei Grube, 1857. Scale bar: $2 \mathrm{~mm}$. Code: UFPB.POL-1726.

b: Pseudonereis gallapagensis Kinberg, 1865. Scale bar: 2 mm. Code: UFPB.POL-1724.

c: Phyllodoce schmardaei Day, 1963. Scale bar: $1 \mathrm{~mm}$. Code: UFPB.POL-1728.

d: Armandia maculata (Webster, 1884). Scale bar: $1 \mathrm{~mm}$. Code: UFPB.POL-1721. 

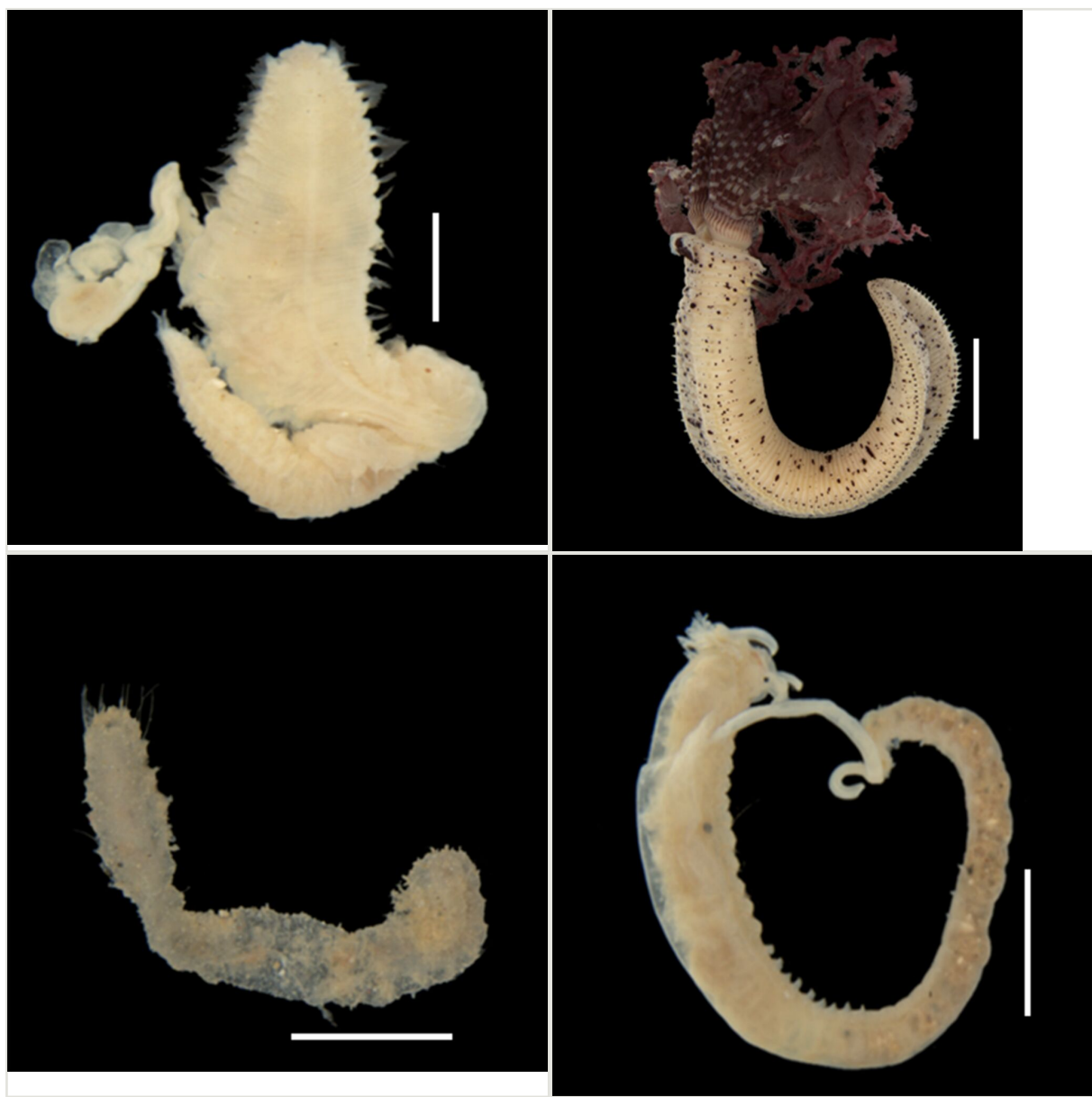

Figure 4.

Identified polychaetes from the Morro de São Paulo, Northeast Brazil. Photos: Prata, J.

a: Hyboscolex longiseta Schmarda, 1861. Scale bar: $1 \mathrm{~mm}$. Code: UFPB.POL-1725.

b: Branchiomma nigromaculatum (Baird, 1865). Scale bar: 5 mm. Code: UFPB.POL-1719.

c: Pherusa scutigera (Ehlers, 1887). Scale bar: 2 mm. Code: UFPB.POL-1729.

d: Terebella plagiostoma Schmarda, 1861. Scale bar: 2 mm. Code: UFPB.POL-1720. 